\section{The Necessity of a European Budget}

\author{
Michel Theys
}

Michel Aglietta \& Nicolas Leron

La double démocratie. Une Europe politique pour la croissance

Éditions du Seuil, Paris, 2017

Here is a book that will warm the hearts and minds of all those who do not resign themselves to seeing Europe as the Member States are building it, destined to certain ruin. Emeritus professor at Paris-Ouest University and adviser at the Center for Prospective Studies and International Information, the economist Michel Aglietta joined researcher Nicolas Leron (Center for European Studies at Sciences Po) in going back to the roots of the current European malaise. These roots are, in their opinion, "structural failures" whose names are "the absence of public power at the European Union level and the incompleteness of the euro". From this intellectual expedition, the reader will come out armed with the conviction that Europe remains more than ever "the right vehicle to meet the great challenges of our time", but that it is high time for the caterpillar to become a butterfly, lest it remains forever a larva in history.

The two authors build their analysis on a conviction: the method of small steps that was dear to Jean Monnet is ineffective because outdated, now that "the economic interest collides with political identity, and the European rules with state sovereignties". Starting from politics and democracy to gauge and understand the European crisis and discerning a way out from the top, they are lead, throughout the pages, to consider it imperative to "rewrite the European constitutive political pact". To this end, they develop a systemic and multidisciplinary analysis of the crisis that takes into account the economic (the organic link between currency and the political sovereign, and between debt and society), political (the Union's political and institutional system and its effects on the national political systems) and legal dimensions (the states' legal sovereignty and the problem of the articulation of the legal orders of the Union and of the Member States, the Court of Justice and the national supreme and constitutional courts).

This enumeration may naturally cause the potential reader to fear that the academic analysis is practically unreadable. This is not so because, while remaining fully faithful to scientific rigor, Aglietta and Leron have the merit of calling a cat a cat and, above all, of ensuring that their economic reasoning does not ignore "the question of political legitimacy", which is the case most of the time, for example when creative beautiful minds formulate "proposals of institutional engineering without great intrinsic scope, like a parliament of the euro zone, or a Finance Minister of the eurozone".

No, what Aglietta e Leron want to do, is to attack the evil at its root, namely, the solution of "the question of politics within the European political system". This evil is "the anemia of politics" which nowadays, in the Union as well as in the Member States, causes "a public impotence" and dissolves the "sovereign", and this so true that "any democracy, whether local, national or European, calls for a parliament endowed with a real budgetary power, able to vote 
fiscal measures and public spending, that is to say, offers citizens the opportunity to decide on significant macroeconomic and societal alternatives". When addressing issues such as the budget or the debt, this is done by ensuring that they are taken into account in the context of "the citizen's belonging and participation in a political order perceived as legitimate". In short, they denounce in a frontal but very argued way "the rupture of the organic link between the political sovereign and the currency" which prevails within the euro zone, with the "vicious circle" which leads the countries and the citizens to lose more than to win, and this "gradually corrodes democracy in Europe".

That is why it is imperative, they argue, to make a transformation of the European constitutive pact and proceed towards the "establishment of a European budget" of 3.5\% of the EU Gross Domestic Product; this budget is to be fed by own fiscal resources, opening "the way to a function of borrower and investor of last resort in Europe". As a result, the European Parliament would gain the status of a "democratic body" in its own right, because it would have a real budgetary power which, in the end, "would give Europeans the possibility of collectively getting into debt as one society for the production of common goods for themselves and future generations". For the authors, a political Europe and European democracy will either be at this price or will not be. Who would dare to say they are wrong? Not many people, certainly, except for many of those who participate in the European Council and other cenacles where the Member States essentially impose the law of their own interests ... 